\title{
Klaas Hendrik Eller*
}

\section{Is ‘Global Value Chain’ a Legal Concept?}

\section{Situating Contract Law in Discourses Around Global Production}

https://doi.org/10.1515/ercl-2020-0002

\begin{abstract}
Today's organization of production and services along global value chains (GVCs) uses contracts as central building blocks, yet is largely disconnected from contract law's dominant epistemology and social imaginary. This article charts when, how and why GVCs have appeared on the radar of contract scholars and unravels the related methodological and disciplinary challenges. Rather than treating GVCs as a 'legal concept' in a strict sense that might command the application of particular rules, I propose to understand them as a 'legal heuristic': GVCs require contract law to revisit its constitutive role for matters of distribution, participation and equality under globalization. Towards this, GVCs need to be understood as organizational arrangement and simultaneously as a stage in the evolution of a global political economy. Beyond the classical confines of 'contract governance', this brings into the picture the wide array of formal and informal technologies of 'contract governmentality'. Together with the material, technological or informational infrastructure, these are referred to as 'code' of GVCs, suggested here as focus of future contract law research on GVCs.
\end{abstract}

Résumé: L'organisation contemporaine de la production et des services tout au long des chaines de valeur globales (CVG) utilise les contrats en tant qu'éléments constitutifs essentiels, mais se départit largement de l'épistémologie dominante en droit des contrats ainsi que de l'imaginaire social. Cet article montre quand, comment et pourquoi les CVG ont été dans la ligne de mire des universitaires du droit des contrats et relèvent des défis connexes à la fois méthodologique et disciplinaire. Au lieu de traiter les CVG comme un concept juridique au sens strict susceptible d'entrainer application de règles particulières, je propose de les considérer comme heuristique. Les CVG mettent au défi le droit des contrats dans son rôle fondamental concernant des grandes questions de distribution, participation

Note: This project has received funding from the European Research Council (ERC) under the European Union's Horizon 2020 research and innovation programme (grant agreement No 756672).

*Corresponding author: Klaas Hendrik Eller, Minerva Post-Doctoral Fellow, Edmond J. Safra Center for Ethics, Tel Aviv University, E-Mail: k.h.eller@uva.nl 
et égalité à l'époque de la mondialisation. Les CVG doivent dans cette optique être appréhendés en tant que structures organisationnelles et en même moment en tant qu'étape dans l'évolution d'une économie politique mondiale. Au-delà des limites classiques de la " gouvernance des contrats », cela prend en compte le large éventail de technologies formelles et informelles de la " gouvernementalité des contrats ». A l'ensemble avec l'infrastructure matérielle, technologique ou informationnelle, celles-ci sont appelées « code » de CVG, qui sera on l'espère l'objet prometteur de la future recherche en droit des contrats sur les CVG.

Zusammenfassung: Die heutige Organisation von Produktions- und Dienstleistungsbeziehungen entlang globaler Wertschöpfungsketten (global value chains GVCs) beruht im Kern auf Verträgen, ist jedoch weitgehend vom Sozialmodell des Vertragsrechts, seiner Epistemologie und normativen Grundorientierung abgekoppelt. Dieser Artikel zeigt auf, wann, wie und warum GVCs in der vertragsrechtlichen Diskussion zum Thema wurden und entfaltet die damit verbundenen methodischen und disziplinären Herausforderungen. Anstatt GVCs im engeren Sinne als ein „Rechtskonzept“ zu behandeln, das bestimmte Rechtsregeln zur Anwendung bringt, schlage ich vor, sie als eine „rechtliche Heuristik“ zu verstehen: Globale Lieferketten fordern das Vertragsrecht dazu heraus, seine konstitutive Rolle für Fragen der Verteilung, der Teilhabe und Gerechtigkeit unter Bedingungen von Globalisierung neu zu überdenken. In diesem Sinne müssen GVCs zugleich als organisatorisches Arrangement zwischen Unternehmen einerseits und als eine Stufe in der Entwicklung einer globalen politischen Ökonomie andererseits verstanden werden. Jenseits der klassischen Grenzen der „Contract Governance“ lenkt dies den Blick auf die breite Palette formaler und informeller Technologien der „Vertragsgouvernementalität“. Zusammen mit der materiellen, technologischen oder informatorischen Infrastruktur, die einer Lieferkette zugrunde liegt, werden diese hier als „Code“ der GVC bezeichnet und als ein Schwerpunkt künftiger vertragsrechtlicher Studien globaler Wertschöpfungsketten vorgeschlagen.

\section{Introduction}

The tension between the generality of the concepts of private law and the specificity of their use in social life is inherent in private law discourses. While the abstractness and decontextualizing nature of concepts like 'contract' and 'legal personhood' accounts in large part for the versatility and evolutionary openness of modern law, these concepts are subliminally linked to a series of normative and actual conditions. In essence, in the example of 'contract', such conditions comprise an idea of contractual justice with regard to a specific archetype that is 
dominated by methodological and normative individualism, ${ }^{1}$ a specific time horizon and presupposes a background justice order provided by the State. ${ }^{2} \mathrm{How}$ ever, the social reality of contract is not constrained to these assumptions; as an infrastructure of social innovation, it is characteristic of contracts to break out of these frames and subject new types of social ordering to the logic of contract. ${ }^{3}$ As contract law's reaction to such a 'contractualization'4 has illustrated on many accounts, this requires basic ideals-normative and factual-to be revisited, or, to echo the creative dimension of this challenge, 'reimagined'.

Today's organization of global production along dispersed networks of suppliers that span the globe represents a most drastic disjunction between the 'social model' ${ }^{5}$ of contract and the way contracts are deployed in practice-a disjunction that is itself conducive to injustice. ${ }^{6}$ Global value chains (GVCs) bind together hundreds, sometimes thousands of suppliers by means of contract and generate

1 Eg C. Fried, Contract as Promise (Cambridge/MA: Harvard University Press, 1981); D. Baird, Reconstructing contracts (Cambridge/MA: Harvard University Press, 2013); for an overview of recent US scholarship in the field E. Zamir, 'Contract law and theory: three views of the cathedral' 81 University of Chicago Law Review 2077-2123 (2014).

2 See eg J. Rawls, A Theory of Justice (Cambridge/MA: Harvard University Press, 1971) who locates the law of contract outside of the realm of application of his principles of justice ('basic structure'). 3 K.H. Eller, 'Transnational Contract Law', in P. Zumbansen (ed), Oxford Handbook of Transnational Law (Oxford: Oxford University Press, 2020, forthcoming).

4 See A. Supiot, 'Les deux visages de la contractualisation : déconstruction du Droit et renaissance féodale', in S. Chassagnard-Pinet and D. Hiez (eds), Approche critique de la contractualisation (Paris: LGDJ, 2007) 19-44; P. Zumbansen, 'The Law of Society: Governance Through Contract' 14 Indiana Journal of Global Legal Studies 191-233 (2007).

5 For the most comprehensive illustration of this concept cf F. Wieacker, Das Sozialmodell der klassischen Privatrechtsgesetzbücher und die Entwicklung der modernen Gesellschaft (Karlsruhe: C.F. Müller, 1953) (social models understood as condensed intellectual assumptions regarding the social order and its legal constitution that underlie the legal process); similarly G. de Almeida Ribeiro, The Decline of Private Law. A Philosophical History of Liberal Legalism (Oxford et al: Hart, 2019), passim (using R. Geuss's 'form of conciousness'); on the irritation of social models through GVCs K.H. Eller, 'Private Governance of Global Value Chains from Within. Lessons from and for Transnational Law' 8 Transnational Legal Theory 296-329 (2017), at 307-309; for a compelling illustration of social models in consumer law M. Bartl, 'Socio-Economic Imaginaries and European Private Law’ Amsterdam Law School Legal Studies Research Paper (No 2019-02); for global governance S. Jasanoff, 'Subjects of reason: goods, markets and competing imaginaries of global governance' 4 London Review of International Law 361-391 (2016).

6 Framed as 'hermeneutical injustice' by L. Tjon Soie Len, 'Hermeneutical Injustice, Contract Law, and Global Value Chains' 16 European Review of Contract Law 139-159 (2020, in this issue). On 'connectivity norms' in global value chains cf P. Kjaer, 'Constitutionalizing Connectivity: The Constitutional Grid of World Society’ 45 Journal of Law and Society 114-134 (2018). 
global interconnections between sites, norms and social dynamics. ${ }^{7}$ The growingly accepted idea that a supply chain as such constitutes a normatively relevant social institution despite its fragmentation in our legal imaginary ${ }^{8}$ is arguably based on the commodified materiality of the produced goods towards which we project normative ideas. Their proliferation has largely altered the (geo-)political, economic but also legal face of the global economy in the last two or three decades. GVCs can be described in microsocial terms as an organizational arrangement between firms, or-applying a macrosocial lens-as a historically contingent ${ }^{9}$ evolutionary stage in the development of capitalism and 'the world economy's backbone and central nervous system' ${ }^{10}$ Besides being a multifaceted empirical reality, the label of 'GVC' pertains to a prominent analytical framework of analysis in the social sciences. Having undergone some shifts in the primary disciplinary references, ${ }^{11}$ the core of GVC analysis today combines influences mainly from organizational sociology, institutional economics and trade and development studies, ${ }^{12}$ notwithstanding an even much broader set of interdisciplinary references in the applications and at the periphery of the framework..$^{13}$ Law, however, continues to be a surprising lacuna; it is yet to be recognised as integral factor within GVC analysis and has not accommodated GVC analysis within its own scholarship. ${ }^{14}$ Current modes of production have become adrift of a legal

7 A. Tsing, Friction: An Ethnography of Global Connection (Princeton: Princeton University Press, 2004).

8 On the remarkable rise of this idea cf K. Sobel-Read, 'Reimagining the Unimaginable: Law and the Ongoing Transformation of Global Value Chains into Integrated Legal Entities' 16 European Review of Contract Law 160-185 (2020, in this issue); for a moral argument A. Bagchi, 'Production Liability' 87 Fordham Law Review 2501-2538 (2019).

9 On the historical background factors conducive to disintegration in the US context cf N.R. Lamoreaux, D. Raff and P. Temin, 'Beyond Markets and Hierarchies: Toward a New Synthesis of American Business History’ 108 The American Historical Review 404-433 (2003).

10 O. Catteneo, G. Gereffi and C. Staritz, 'Global Value Chains in a Postcrisis World: Resilience, Consolidation, and Shifting End Markets', in O. Catteneo, G. Gereffi and C. Staritz (eds), Global Value Chains in a Postcrisis World: A Development Perspective (Washington: The International Bank for Reconstruction and Development/The World Bank, 2010) 3, 7.

11 J. Bair, 'Global Capitalism and Commodity Chains: Looking Back, Going Forward' 9 Competition and Change 153-180 (2005).

12 See G. Gereffi (ed), Global Value Chains and Development. Redefining the Contours of $21^{\text {st }}$ Century Capitalism (Cambridge: Cambridge University Press, 2018); S. Ponte, G. Gereffi and G. Raj-Reichert (eds), Handbook on Global Value Chains (Cheltenham: Edward Elgar, 2019).

13 Those include approaches as varied as theories of justice, women's studies, labour, historical materialism, cultural studies and science and technology, to name just a few.

14 For a broader analysis of the lacunae in legal discourse cf IGLP Law and Global Production Working Group, 'The role of law in global value chains: A research manifesto' 4 London Review of International Law 57-79 (2016). 
conceptualization and stand diagonal to legal dichotomies. The so far marginal role of law in GVC scholarship is surprising in light of the intuitive significance of law and especially contracts in the formation of GVCs. To orchestrate up to 19,000 suppliers globally as in the value chain of semi-conductor chip manufacturer Intel ${ }^{15}$ would be impossible without modern communication and logistics technology, to be sure, yet ultimately the industrial revolutions each coincided with 'organizational' revolutions that were facilitated by private law. ${ }^{16}$ At a time when contract is more and more becoming a tool of social, not merely bilateral, ordering, ${ }^{17}$ the translation of the challenges linked to this transformation in contract theory is at best in its infancy. Recent trends in contract theory in fact rather advocate a decontextualized, universalistic model instead of a more pluralistic, societally receptive type of thinking about contracts. ${ }^{18}$

Against this background, this article aims at unfolding the methodological and disciplinary challenges posed by GVCs in their various emanations by focusing on their use of contract and by situating law within a growingly heterogenous yet dynamic research around global production. Towards this end, it will in a first step retrace the gist of past legal preoccupations with global supply chains (II). It will become clear that while such inquiries have some pedigree in various fields of private law, it is only recently and under the influence of interdisciplinary work that the inner fragmentation of private law discourses is transcended and GVCs become a social unit of analysis in their own right. This raises the notorious question, familiar from the debate around network contracts, if and to what extent GVCs can or should be considered a 'legal concept', ie be defined in genuinely legal language and entail the application of a somewhat standardized set of rules (III). This would, indeed, follow a common inclination among legal scholars when unravelling a new social reality in its legal dimension. My claim will be, however, that this intuition

15 Cf K. Crawford and V. Joler, 'Anatomy of an AI System' (2018), available at anatomyof.ai/img/ ai-anatomy-map.pdf.

16 J. Osterhammel, The Transformation of the World. A Global History of the Nineteenth Century (Princeton: Princeton University Press, 2014) 669-670 (highlighting the novel form of organization of production, in addition to merely increased 'exchange and circulation', as distinctive feature of the first Industrial Revolution of the $19^{\text {th }}$ century); furthermore R. Baldwin, 'Trade and Industriali-

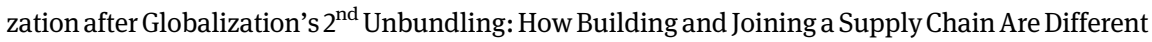
and Why It Matters', in R. Feenstra and A. Taylor (eds), Globalization in an Age of Crisis: Multilateral Economic Cooperation in the Twenty-First Century (Chicago: Chicago University Press, 2014) 165212.

17 Cf. B. Lomfeld and D. Wielsch, 'The Public Dimension of Contract: Contractual Pluralism Beyond Privity’ 76 Law and Contemporary Problems i-xii (2013).

18 For an overview L. Herrine, 'Socializing Contract' (30 May 2019), available at SSRN: https://ss rn.com/abstract $=2989173$. 
should be resisted for two reasons: Firstly, because it would sustain an overly homogenous vision of the current landscape of supply chains, and secondly, because GVCs raise questions many of which are too principled to be addressed by reference to some legislative act or conceptual innovation as such. Instead of narrowing the challenge down to the search for a 'silver bullet' of legal intervention ('what works"19), it seems preferable to read the rise of GVCs more broadly as an epiphenomenon of the need to adjust private law's toolkit to a global and networked society. In this perspective, the label of 'global value chain' can most helpfully serve as heuristic and provide guidance for the ambition to confer to private law-and contract law in particular-a more eminent position in the responses to struggles of distribution, participation and equality under globalization. The proposed solution conceives of GVCs as a social institution, just like the 'firm' and the 'market', and hence acknowledges that next to legal elements, economic, cultural, political or moral factors form part of the story. ${ }^{20}$ This assemblage of different social dimensions of a GVC draws attention, inter alia, to the role of material, technological and digital infrastructure and its relation to law. Law's role becomes to mediate between the different dimensions of a GVC, in other words: to ascertain that the economic rationale that brings a GVC into being remains compatible with the integrity of social life in which GVCs unfold. Some reflections on new methodological alliances that result from such an ambition shall conclude (IV).

\section{A Genealogy of Private Law Preoccupations with Global Production}

Global supply chains have not originated as a legal concept, let alone as a topic of thorough legal interest. The disciplinary origins of value chain analysis can be located in a political economy of development, namely Wallerstein's World Systems Theory ${ }^{21}$ as first adapted in the previous 'Global Commodity Chain' (GCC)

19 For a such framing A. Rühmkorf, 'Global Supply Chain Governance: The Search for What Works' 23 Deakin Law Review 63-82 (2018).

20 For an illustration with regard to the multiple connotations of the concept of 'responsibility' along GVCs K.H. Eller, 'Das Recht der Verantwortungsgesellschaft' 10 Rechtswissenschaft 5-33 (2019); spelled out as a theory of justice D. Wielsch, 'Relational Justice' 76 Law and Contemporary Problems 191-211 (2013).

21 T.K. Hopkins and I. Wallerstein, 'Commodity Chains: Construct and Research', in G. Gereffi and M. Korzeniewicz (eds), Commodity Chains and Global Capitalism (Westport: Greenwood Press, 1994) 17-19. 
framework. ${ }^{22}$ This macro-level theorization was embedded in a fully-fledged theory of globalization and presented implications primarily for international and regional trade regimes, challenging the idea that production activities can be broken down on a country-by-country basis. Hence, its legal reception occurred, if at all, in the fields of international and trade law. Developed as an outgrowth of the GCC framework and by a similar network of scholars, today's dominant frame of analysis-global value chains (GVCs) ${ }^{23}$-adopts in essence a micro-level perspective that centres around the relations between 'lead firms' and its core suppliers of the first tiers downstream. This concentration on the governance of identifiable supplier relationships decontextualizes them from macro-level surrounding factors. To be sure, this has allowed the GVC framework to become a globally used toolkit for industrial policy reform, while at the same time restricting its ties with critical theory-building on political economy and distributive justice as well as the non-economic implications of GVCs. ${ }^{24}$

The key concepts of the GVC approach, notably 'value creation', ${ }^{25}$ 'upgrading ${ }^{26}$ and 'governance, ${ }^{27}$ speak more explicitly to private lawyers than the GCC framework. Private law provides the means of coordination across tiers and enables firms to locate themselves within a competitive web of market clusters. As a consequence, global supply chains have indeed a considerable pedigree in contract governance and theories of law and social norms that shall be presented below. Here, legal analysis takes an internal perspective of value chain participants and asks how their arrangement can be optimized. What is hitherto missing yet slowly emerging is a combination of such approaches with an external perspective that places GVCs in their political economy and broader social context. This conceives of GVCs (also) as a legal construct that largely preconfigures social life across various fields and geographical spaces.

22 G. Gereffi, M. Korzeniewicz and R.P. Korzeniewicz, 'Introduction: Global Commodity Chains', in Gereffi and Korzeniewicz (eds), n 21 above, 1-14.

23 For recent and comprehensive illustrations see Gereffi (ed), n 12 above and Ponte, Gereffi and Raj-Reichert (eds), n 12 above.

24 For a critical genealogy cf J. Bair, ‘Global Commodity Chains: Genealogy and Review’, in J. Bair (ed), Frontiers of Commodity Chain Research (Stanford/CA: Stanford University Press, 2009) 1-34.

25 R. Kaplinsky and M. Morris, 'The Structure of Supply Chains and Their Implications for Export Supply', Paper prepared for the African Economic Research Consortium, June 2007.

26 See eg J. Humphrey, 'Upgrading in Global Value Chains', ILO Policy Integration Department, Working Paper No 28 (2004).

27 See eg P. Gibbon, J. Bair and S. Ponte, 'Governing global value chains: An introduction' 37 Economy and Society 315-338 (2008); M.P. Dallas, S. Ponte and T. Sturgeon, 'Power in Global Value Chains‘ 26 Review of International Political Economy 666-694 (2019). 
The deeper reasons for this persistent lacuna in legal scholarship, I contend, exceed the case of global production and pertain to the unacknowledged role of social institutions in private law at large. Methodological individualism entails a social theory which conceives of social dynamics as unleashed by individuals and evaluates them against their effects on individuals. To the extent individual action becomes subject to justification, each and every manifestation of private autonomy is seen as separable from its social context. ${ }^{28}$ Aggregate dynamics and entanglements arising from the repeated and decentral use of private autonomythe factors that make value chains closed-circuit regimes-fall outside of the picture. ${ }^{29}$ This becomes obvious when looking at the genealogy of legal contributions to an interdisciplinary body on global production. Legal works have long been selective and fragmented by legal sub-fields. At a more general level, this is illustrative of the overlooked role of private law in debates around challenges of global governance in many fields-from climate change to financial stability. ${ }^{30}$ Private law here falls victim to an imaginary of private governance as a 'natural order ${ }^{31}$ driven by an efficient institutional design. In this view, propelled in institutional economics, private law becomes instrumental towards naturalized party interests and thereby external and pre-determined, rather than a constitutive factor of its own. Underlying this imaginary is an ascription of public concerns to a public law infrastructure, a legal array that comes into play only once the social institutions summoned by private law are already established. This not only overlooks the centrality of contract for the current allocation of power, wealth and resources but also offers little insight into how public law requirements can translate into the fine-grained contractual structure of a chain. This omission ultimately leads to a problem of circularity: In dealing with global production which in part draws on a strategic play with niches of modern law, legal scholarship finds itself in the same loops, paradigms and path-dependencies that need to be

28 Interestingly, in the case of distributive justice, even libertarian theories of justice are concerned with the way justice principles lead to specific 'patterns', cf R. Nozick, Anarchy, State, and Utopia (New York: Basic Books, 1974). In contract law, such 'current time-slice principles of justice'-that would capture the outcome of an initial guarantee of private autonomy-are not usually discussed.

29 E.-J. Mestmäcker, 'Über die normative Kraft privatrechtlicher Verträge’ 19 Juristenzeitung 441446 (1964) 441 ('Die Frage nach der rechtlichen Qualität der aus dem Vollzug der rechtsgeschäftlichen Privatautonomie entstehenden sozialen Wirklichkeit hat die zivilrechtliche Dogmatik bis in unsere Zeit aus ihrer Betrachtung ausgeschlossen.').

30 Cf most recently K. Pistor, Code of Capital: How the Law Creates Wealth and Inequality (Princeton: Princeton University Press, 2019).

31 B. Harcourt, The Illusion of Free Markets. Punishment and the Need of Natural Order (Cambridge/MA: Harvard University Press, 2012). 
questioned to engage with global production. In other words, a legal analysis of global production needs to be distinctively imaginative and epistemologically attentive to leave a mark.

It is worthwhile to recapitulate-in a necessarily sketchy way-the trajectory of private law scholarship on global supply chains with the aim of illustrating when, why and how the current peak of interest devoted to new forms of production arose. Chains of production entered the arena of private law scholarship as a curious hybrid between market and firm, 'make or buy'. Existing typologies of governance use this antagonism as analytical grid to study the mechanisms used to coordinate along chains with varying degrees of vertical integration. ${ }^{32}$ Depending on one's starting point, the ambition becomes either to deal with a disintegration of the corporate actor along supply chains (thus reading decentral evolution into the 'firm') or with an interdependence of bilateral contracts (thus reading coordination into 'contract'). For the latter, Coase's ${ }^{33}$ landmark article dealt with reasons for using central entities in the first place, and he identified lower transaction costs as compared to markets as principal reason. For the former, various pieces today inquire how the corporate actor is genuinely pluralistic and decentralized across the boundaries of the corporate form. ${ }^{34}$ Both ways of approaching GVCs illustrate how much a framework for GVCs is a matter of perspective, since GVCs-to a bigger extent even than previous modes of production ${ }^{35}$-simultaneously challenge multiple legal categories and dogmas. These include, for instance, key concepts of fields as variegated as contract ('privity', 'promise'), corporate and tort law ('corporate veil') and international private law (national attribution of conflicts). Despite their presumed heterogeneity, the aforementioned concepts have common roots in the individualistic liberal orientation of modern

32 See J. Salminen, 'Towards a Genealogy and Typology of Governance Through Contract Beyond Privity' 16 European Review of Contract Law 25-43 (2020, in this issue).

33 R. Coase, 'The Nature of the Firm' 4 Economia 386-405 (1937).

34 J. Bair, 'The Corporation and the Global Value Chain', in G. Baars and A. Spicer (eds), The Corporation. A Critical, Multi-disciplinary Handbook (Cambridge: Cambridge University Press, 2017) 326-335; D. Danielsen, 'Beyond corporate governance. Why a new approach to the study of corporate law is needed to address global inequality and economic development', in U. Mattei and J. Haskell (eds), Research Handbook on Political Economy and Law (Cheltenham: Edward Elgar, 2015) 195 et seq; M. Amstutz, Globale Unternehmensgruppen. Geschichte und Zukunft des europäischen Konzernrechts (Tübingen: Mohr Siebeck, 2017) and G.-P. Calliess and S. von Harder, 'Firmeninternes Handelsrecht, Vertragsdurchsetzung und Streitbeilegung in transnationalen Unternehmen' 33 Zeitschrift für Rechtssoziologie 207 (2012/3).

35 For an early account of co-evolution between law and production regimes $\mathrm{cf} \mathrm{G}$. Teubner, 'Idiosyncratic Production Regimes: Co-evolution of Economic and Legal Institutions in the Varieties of Capitalism' 112 Proceedings of the British Academy 161-182 (2002). 
law, namely in their limited ability to account for the interdependence of various chain actors across boundaries of nation-states or legal personhood. Against this background, it is hardly surprising that competition law with its higher sensitivity towards actual market dynamics, power relations and distributive effects is receiving more attention recently in regulating salient matters in GVCs, including private restrictions to trade. ${ }^{36}$

The elusiveness of GVCs in legal terms raises foremost epistemological questions: How does and should (private) law perceive of GVCs, this economic institution that criss-crosses legal dichotomies and is inherently hard to visualize and epitomize? Along the lines of which imaginary, that is metaphors, semantics, and pictorial ideas ${ }^{37}$ does law approach this new reality of production? And ultimately: Cui bono-who benefits from the respective implications of metaphors and public imagination? Depending on what is regarded as the principal legal building-blocks of GVCs, the analytical focus and normative concern may vary greatly: normative and conceptual analysis can no longer be neatly separated but are highly interlinked. ${ }^{38}$

\section{Coming From Afar: Contract Law's Epistemology and Global Production}

Contract law seems an obvious and privileged lens for the study of GVCs. From the perspective of participants in complex chains and most importantly the lead firm, contracts form the tender spot towards ensuring the innovation generated through the GVC. Yet, a (neo-)formalist contract theory which stands emblematically for the Western epistemology of contract ${ }^{39}$ would assume there to be much ado about

36 On the descriptive and analytical potential of the 'global value chain'-framework for competition law cf I. Lianos, 'Global Food Value Chains and Competition Law. BRICS Draft Report' UCL Center for Law, Economics and Society (CLES) Research Paper 2/2017, 30 et seq. For a joint contract (unconscionability) and antitrust (abuse of dominance) assessment of a supplier agreement between the Volkswagen Group and a key supplier, the Prevent Group, see LG Dortmund of 27 February 2019-8 0 19/18 Kart, ECLI:DE:LGDO:2019:0227.8019.18KART.00.

37 Eg D. Damler, Konzern und Moderne. Die verbundene juristische Person in der visuellen Kultur 1880-1980 (Berlin: Duncker \& Humblot, 2016) and recently B. Brożek, The Legal Mind. A New Introduction to Legal Epistemology (Cambridge: Cambridge University Press, 2019).

38 See similarly P. Zumbansen, 'Politicizing the Law of Global Value Chain Capitalism' 1 Journal of Law and Political Economy (2020, forthcoming).

39 On its genealogy and its cultural and epistemological underpinnings cf R. Kreitner, Calculating Promises (Stanford: Stanford University Press, 2007); for a general epistemological theory of law G. Teubner, 'How the Law Thinks: Toward a Constructivist Epistemology of Law' 23 Law \& Society 
nothing: GVCs appear as a mere sequence of contracts-the label of 'GVC' then appears as a legal mystification or mirage. Contract scholarship, as this shows, had to come a long way to discern the distinctiveness of contract in a GVC setting-its systemic references across texts and norms, its regulatory underpinnings, its shifting role for a multi-faceted set of social and business norms, both local and sectoral, and finally its location within a spatialized assemblage of global capitalism. Since such features were epistemologically off the radar, legal scholarship was educated about relational, symbiotic, organizational or network elements of GVC contracts $^{40}$ through legal practice. Just like in Macaulay's empirical study that initiated 'relational' contracting research, ${ }^{41}$ a phenomenology of contract in GVCs reaches beyond written contracts and legal safeguards ${ }^{42}$ and includes various mechanisms of trust-building in order to ensure a cooperative spirit over time.

However, this proximity to 'practice' has not been without consequences for the focus and the methods of inquiry, which have been largely placed on the contractual design among the first tiers. ${ }^{43}$ As in the case of the Toyota lean production model, ${ }^{44}$ this particular segment of the chain often contains the business model's actual innovation translated into contract law. In championing novel contractual design, contract scholarship adopted an internal perspective of chain participants, or rather its most upstream tiers, that remained closely driven by efficiency

Review 727-758 (1989); on alternative epistemologies in and beyond legal thinking B. Santos, The End of the Cognitive Empire: The Coming of Age of Epistemologies of the South (Durham and London: Duke University Press, 2018).

40 Pioneering on relational contracting are S. Macaulay, 'Non-contractual Relations in Business: A Preliminary Study' 28 American Sociological Review 55-67 (1963) and I. MacNeil, 'Contracts: Adjustment of Long-Term Economic Relations under Classical Neoclassical and Relational Contract Law' 72 Northwestern University Law Review 854-905 (1978). These basic tenets have been theorized along different lines in their projection to more contemporary forms of economic organization in E. Schanze, 'Symbiotic Contracts: Exploring Long-Term Agency Structures Between Contract and Cooperation', in C. Joerges (ed), Franchising and the Law. Theoretical and Comparative Approaches in Europe and the United States (Baden-Baden: Nomos, 1991) 67-104; G. Teubner, Network as Connected Contracts. Edited with an Introduction by Hugh Collins (Oxford: Hart, 2011) and S. Grundmann, F. Cafaggi and G. Vettori (eds), The Organizational Contract - From Exchange to Long-Term Network Cooperation in European (Farnham et al: Ashgate, 2013).

41 Cf Macaulay, $\mathrm{n} 40$ above.

42 Eg R. Gilson, C. Sabel and R. Scott, 'Braiding: The Interaction of Formal and Informal Contracting in Theory, Practice, and Doctrine' 110 Columbia Law Review 1377-1447 (2010).

43 R. Gilson, C. Sabel and R. Scott, 'Contracting for Innovation: Vertical Disintegration and Interfirm Collaboration' 109 Columbia Law Review 431-502 (2009); on the reach of first tier-suppliers see G. Raj-Reichert, 'The role of transnational first-tier suppliers in GVC governance', in Ponte, Gereffi and Raj-Reichert (eds), n 12 above, 354-369.

44 W. Simon, 'Toyota Jurisprudence: Legal Theory and Rolling Rules Regimes', in G. de Búrca and J. Scott (eds), Law and New Governance in the EU and the US (Oxford: Hart, 2006) 37-64, 38 et seq. 
and risk distribution and based on implicit assumptions of knowledge, stability and formality of the institutional setting. In addition, taking such a firm-level perspective was stimulated by a similar orientation in the GVC analysis conducted in social sciences. ${ }^{45}$

\section{From Contractual Networks to Global Value Chains}

Private law scholarship has approached trade in global supply chains essentially coming from two conceptual angles, one of which can generally be termed 'private governance', ie the demonstration to what extent privately crafted legal regimes can replicate and effectively replace state-made law for a specific industry ${ }^{46}$ and the other of which was 'contract governance', ${ }^{47}$ ie an inquiry into the tools and motivations to include concerns of institutional cooperation and adjustment into bi- and, even more so, multilateral contracts. Both angles found an earlier culmination in a debate around contractual networks that arose in the late 1990ies. A manifest shift in business organization towards accelerated just-intime networks, franchises and distribution networks challenged the (neo-)classical grid of contract thinking and spurred a debate around the adequacy of the existing legal framework to respond. ${ }^{48}$ General structural features of network con-

45 See A. Beckers, 'The invisible Networks of Global Production: Re-Imagining the Global Value chain in Legal Research' 16 European Review of Contract Law 95-117 (2020, in this issue).

46 Locus classicus is Lisa Bernstein's series of industry studies on diamonds, grain and cotton, cf L. Bernstein, 'Opting Out of the Legal System: Extralegal Contractual Relations in the Diamond Industry' 21 Journal of Legal Studies 115-157 (1992); L. Bernstein, 'Merchant Law in a Merchant Court: Rethinking the Code's Search for Immanent Business Norms' 144 University of Pennsylvania Law Review 1765-1821 (1996) and L. Bernstein, 'Private Commercial Law in the Cotton Industry: Creating Cooperation Through Rules, Norms, and Institutions' 99 Michigan Law Review 1724-1790 (2001).

47 S. Grundmann, F. Möslein and K. Riesenhuber, 'Contract Governance: Dimensions in Law and Interdisciplinary Research', in S. Grundmann, F. Möslein and K. Riesenhuber (eds), Contract Governance: Dimensions in Law and Interdisciplinary Research (Cambridge: Cambridge University Press, 2015) 3-60; J. Salminen, 'Contract-Boundary-Spanning Governance Mechanisms: Conceptualizing Fragmented and Globalized Production as Collectively Governed Entities' (2016) 23 Indiana Journal of Global Legal Studies 709; M.P. Vandenbergh, 'The New Wal-Mart Effect: The Role of Private Contracting in Global Governance' 54 UCLA Law Review 913-970 (2007); most recently F. Bremenkamp, Rechtliche Governance von Zulieferverträgen. Eine vergleichende Untersuchung in der Automobilindustrie nach deutschem, englischem und italienischem Recht ( $\mathrm{PhD}$ thesis, Humboldt-University of Berlin, 2019).

48 See for overviews M. Amstutz and G. Teubner (eds), Networks. Legal Issues of Multilateral Cooperation (Oxford: Hart, 2009); H. Collins, 'Introduction to “Network as Connected Contracts”, in 
tracts were described as bilateral contracts which (1) contain mutual references to one another, either explicitly or within actual contractual practice, (2) include a connection with the common project and (3) are part of an effective and co-operative relationship between associated members. ${ }^{49}$

'Contractual networks' commanded law to reflect upon the contingencies and institutionalized tensions between a bilateral black-letter design and its multilateral effects, between hierarchy and market as well as between cooperation and competition. More specifically, a judicial or regulatory response was to be identified that would re-state (otherwise invisible, yet crucial) network expectations vis-à-vis individual party behaviour. Case scenarios would include both internal apportionment of liability as well as external liability towards clients, both commercial or consumer.

Since such 'network contracts' present some clear parallels to the contemporary realities of Global Value Chains with regard to the functional collaboration across tiers and a distinct 'network rationality', their analysis forms a central repository and sometimes an explicit reference ${ }^{50}$ for GVCs. Yet, this prior debate does not qualify as blueprint for a contract law approach to GVCs because of at least two factors pertaining to a different scope, methodology and scholarly ambition.

(1.) GVCs share many features of networks, while not stricto sensu forming one itself. This is because GVCs (when considered down to their final and often informal tier ${ }^{51}$ at least) lack the 'abstract reciprocity', 52 'common purpose' or some mutual (implicit) agreement as to the distribution of benefits that characterizes networks. Such an agreement of whatever type will typically exist among the leading tiers which have an established business relation, including relation-specific investments and trust. Beyond these tiers that are the beneficiaries of 'up-

Teubner, $\mathrm{n} 40$ above, 1-72; I. Augsberg, 'The Relevance of Network Models within the Juridic Discourse. Empirical, Sociological, and Epistemological Perspectives' 10 German Law Journal 383-394 (2009), S. Grundmann, 'Die Dogmatik der Vertragsnetze' 207 Archiv für die civilistische Praxis 718767 (2007).

49 G. Teubner, Netzwerk als Vertragsverbund (Baden-Baden: Nomos, 2004) 117.

50 Cf Salminen, $\mathrm{n} 47$ above, 737-740.

51 For a recent illustration of informality at the periphery of GVCs cf M. von Oppenkowski, M. Hassler and T. Roesler, 'Informal markets and global value chains. The Disembedding of Romanian dairy smallholders' 27 European Planning Studies 995-1012 (2019).

52 Cf Teubner, n 49 above, 10-11; on multilateral reciprocity J. Köndgen, Selbstbindung ohne Vertrag (Tübingen: Mohr Siebeck, 1981) 248 et seq; generally on the social characteristics of 'networks' H. Knox, M. Savage and P. Harvey, 'Social networks and the study of relations: networks as method, metaphor and form' 35 Economy and Society 113-140 (2006). 
grading, ${ }^{53}$ the delineation of actors to be included in a GVC and an actual distributive arrangement becomes fuzzy. As it stands, GVCs have much more elusive and informalized boundaries than the textbook examples of networks. Especially rapidly changing suppliers of basic inputs at the periphery of a GVC will oftentimes not be able to see their contribution as part of a collective assemblage. Moreover, given the drastic imbalance of power and participation in value generation along GVCs ${ }^{54}$ the respective interests are rather antagonistic, like in the classical contractual model. This is illustrated by price squeeze and short delivery times that benefit the respective chain participants very unevenly. Overall, the idea of a 'common purpose' appears as too harmonious, comfortable and ultimately fictitious for the reality of GVCs. What unfolds along the chain and binds actors between centre and periphery of a chain together is not a joint enterprise of any shape, but an animating production logic as the telos of a chain. This chain rationality is both source of welfare and opportunities for development and conducive to further inequality..$^{55}$ To study how this production logic unfolds requires to focus on its normative and material basis (see below III).

(2.) A second important reason to not fully conflate the previous network debate with the challenges through GVCs relates to the scholarly ambition. For networks, the starting point was the fundamental question if there is room for a third legal category beyond contract (market) and firm (property) and to what extent 'networks' would be a genuine 'third' ${ }^{56}$ or composite of the existing. A primary concern was how not to jeopardize specific cooperative gains and distort innovation provided for by network participants. In this regard, the debate was curtailed to the micro-level continuum between 'firm' and 'market' together with an emphasis on a national legal order in the background. Moving along this continuum does not however allow the capture of the perspective added by the GVC framework. This has implications for the interdisciplinary references that GVCs suggest or rather presuppose. Even beyond the set of insights from institutional economics and new economic sociology that made the analysis of network contracts a genuinely interdisciplinary endeavour, ${ }^{57} \mathrm{GVCs}$ require scholarship to bridge the gaps

53 See for a straightforward view on the promises of 'upgrading' World Bank, 'Trading for Development in the Age of Global Value Chains', World Development Report 2020.

54 Dallas, Ponte and Sturgeon, $\mathrm{n} 27$ above.

55 See eg D. Quentin and L. Campling, 'Global inequality chains: Integrating mechanisms of value distribution into analyses of global production' 18 Global Networks 33-56 (2018).

56 For this argument cf W. Powell, 'Neither Market nor Hierarchy: Network Forms of Organization' 12 Research in Organizational Behavior 295-336 (1990).

57 Cf S. Grundmann, '”Towards” a Private Law Embedded in Social Theory: Eine Skizze’ 3-4 European Review of Private Law 409-424 (2016). 
and blind spots that GVCs play with, including local vs global, private vs public, formal vs informal, agency vs systemicity, normativity vs materiality. Thereby, anthropology arguably assumes a significance in the study of GVCs that resembles the pivotal role of organizational sociology and institutional economics with regard to networks. It adds critically to these disciplines by capturing, for instance, the various degrees of informality ${ }^{58}$ and legality ${ }^{59}$ that are employed at the bottom tiers of GVCs. More specifically, it makes intuitive the finding that what is often termed as 'externalities' of a GVC is by no means a stable, exogenous group of effects but rather a constructed category of effects that are outside of the dominant frameworks of contract in its institutional economic reading. ${ }^{60}$

By placing GVCs within a broader perspective of development and trade, lawyers are invited to go beyond the established idea that GVCs take their particular shape simply because of the market-enabling dimension of private autonomy beyond the state ${ }^{61}$ whose lack of social embeddedness is further fostered by the privatization of its enforcement. ${ }^{62}$ Rather, GVCs are social institutions based on normative and behavioural regularities whose genealogy can only be fully elucidated when read in the light of more macro-level factors of geo-political transformations and political economy that are rarely connected to contractual analysis. This explains why the transformations in private law over the course of the $20^{\text {th }}$ away from classical legal thought ${ }^{63}$ that sought to adjust private law to more realist or

58 For a compelling illustration of anthropological GVC analysis and their private legal reconstruction cf L.D. Knöpfel, 'A Legal Anthropological Reimagining of Contract in Global Value Chains: Relations between Mining Firms and Local Communities at Corporate Frontiers' 16 European Review of Contract Law 118-138 (2020, in this issue); for a related claim Zumbansen, n 38 above.

59 On this see M. Viljanen (in this issue); furthermore J. Norpoth and C. Scheper, 'Qualifying Legal Force in Transnational Labour Regulation: The Case of the Bangladesh Accord on Fire and Building Safety', paper presented at the workshop “5 Years After Rana Plaza: Consequences for Labor Standards', Free University of Berlin, Faculty of Business and Economics, 27-28 April 2018 (on file with author).

60 On the legal construction of externalities, see R. Coase, 'The Institutional Structure of Production' 82 The American Economic Review 713-719 (1992).

61 On private autonomy in the transnational sphere cf H. Muir Watt, "'Party Autonomy” in international contracts' 6 European Review of Contract Law 250-283 (2010); F. Rödl, 'Private Law Beyond the Democratic Order? On the Legitimatory Problem of Private Law "Beyond the State” 56 American Journal of Comparative Law 743-767 (2008).

62 A.C. Cutler, Private Power and Global Authority (Cambridge: Cambridge University Press, 2003).

63 Cf most recently D. Kennedy, 'A Political Economy of Contemporary Legality', in P.F. Kjaer (ed), The Law of Political Economy: Transformations of the Function of Law (Cambridge: Cambridge University Press, 2020, forthcoming); also de Almeida Ribeiro, n 5 above. 
'social' conceptions of autonomy century have had relatively little traction on GVCs.

\section{Global Value Chains and Private Law: Legal Concept, Methodology or Heuristic?}

After having seen that GVCs are not, in their conceptual challenges to private and contract law, a mere extension and continuation of the debate around 'network contracts', the question remains as to how private law should unpack its own constitutive role in GVCs. Is it to be expected that an emerging 'law of global value chains' ${ }^{\prime 64}$ shall be turned into a comprehensive field of legal analysis, or is it even appropriate to elevate 'global value chain'-as has famously been discussed for contractual networks ${ }^{65}$-to the status of a legal concept itself, commanding the application of a particular set of rules that may differ from other forms of contractual organization of production? I will argue that such homogenizing attempts should be resisted ${ }^{66}$ and that GVCs should primarily be seen as a methodological challenge and heuristic for a broad series of private law inquiries.

\section{From Contract Governance to Contract Governmentality}

Law enjoys broad discretion when it comes to marking 'legal concepts' ${ }^{97}$-it can even be argued that providing a plurality of legal arrangements is fulfilling re-

\footnotetext{
64 For this wording cf Zumbansen, n 38 above; J. Salminen and M. Rajavuori, 'Transnational sustainability laws and the regulation of global value chains: Comparison and a framework for analysis' 26 Maastricht Journal of European and Comparative Law 602-627 (2019).

65 R.M. Buxbaum, 'Is "Network" a Legal Concept?' 149 Journal of Institutional and Theoretical Economics 698-705 (1993); G. Teubner, 'Coincidentia oppositorum: Hybrid Networks Beyond Contract and Organisation', in Amstutz and Teubner (eds), n 48 above, 3-30; for a summary H. Collins, 'Networks and Comparative Sociological Jurisprudence', in Festschrift für Gunther Teubner zum 65. Geburtstag (G.-P. Calliess et al [eds], Berlin: de Gruyter, 2009) 249-260.

66 See for a similar critique of a homogenizing concept of contract R. Scott, 'The Paradox of Contracting in Markets', Law and Contemporary Problems (2020, forthcoming).

67 See recently on the implications H. Collins, 'Is a Relational Contract a Legal Concept?', in S. Degeling, J. Edelman and J. Goudkamp (eds), Contract in Commercial Law (Pyrmont, NSW: Thomson Reuters, 2016) 37-59.
} 
quirements of justice. ${ }^{68}$ Yet, it would ultimately constitute a too narrow reception of global value chains within private law to respond by the delineation of a new 'legal concept'. To be sure, some sets of rules and adjustments to a conventional transactional model of contract law have compellingly been identified ${ }^{69}$ and recent legislation requiring transparency and due diligence across many countries each comes with an idea of the structure of a GVC. ${ }^{70}$ Despite the ambition to address matters such as sustainability 'along GVCs', upon closer inspection, many of these pieces of legislation capture only the first tiers of a GVC and have difficulty accommodating their complexity. This illustrates that a syllogistical understanding of GVC could not possibly do sufficient justice to the fact that there is no generic type of GVC-rather, transactional techniques are calibrated upon industry, geographic and supply-chain related specificities and may vary according to the climate in international trade. ${ }^{71}$ This is reflected by the fact that GVC analysis does not itself entail a theory of the firm and is relatively pragmatic about the boundaries of the framework, such as with regard to including groups like consumers, employers, NGOs or others.

Instead, I posit that GVCs can best inform legal analysis as a 'legal heuristic', namely a combination of empirical and normative challenges to basic tenets of private law reasoning. For an understanding of GVCs as a 'legal heuristic' which urges (private) law to reconsider its role at an evolutionary stage of capitalism, the conceptual openness of the GVC analytic is not per se troubling. When treated as a methodological challenge ${ }^{72}$ (alongside the substantive elements of concern), GVCs would not be parcelled into established doctrinal categories; rather, a persistent coevolution of these very categories would be assumed. This does not entail to reinvent the wheel in conceptual terms and acknowledges, albeit on a cautious note, the long pedigree of many relevant questions in legal thought. In this perspective, doctrinal work on the classification of GVC contract clauses into established cate-

68 See for contract types H. Dagan and M. Heller, The Choice Theory of Contracts (Cambridge: Cambridge University Press, 2017); for property types H. Dagan, 'Autonomy and Property', in H. Dagan and B. Zipursky (eds), Research Handbook on Private Law Theories (Cheltenham: Edward Elgar, 2020, forthcoming).

69 Most notably F. Cafaggi and P. Iamiceli, 'Contracting in global supply chains and cooperative remedies' 20 Uniform Law Review 135-179 (2015); F. Cafaggi, 'Regulation Through Contracts: Supply-Chain Contracting and Sustainability Standards' 12 European Review of Contract Law 218-258 (2016).

70 See Salminen and Rajavuori, $n 64$ above.

71 Cf F. Cafaggi and P. Iamiceli (in this issue).

72 See for comparable arguments with regard to the term of 'transnational law' G.-P. Calliess and P. Zumbansen, Rough Consensus and Running Code. A Theory of Transnational Private Law (Oxford: Hart, 2010). 
gories, eg of third-party beneficiary rules, promissory estoppel and others ${ }^{73}$ is sometimes confronted with the problem of referring to overly stable legal doctrines, in a field dominated by emerging legal frameworks, uncertainty and a predominance of informal mechanisms over black-letter contract clauses as in relational contracting.

The fluidity and informality of governance mechanisms especially on the ground can be captured by broadening classical 'contract governance' frameworks in favour of an approach of 'contract governmentality'. Drawing on Foucault's illustration of informal and subtle modes of governance that are in the folds of a public-private law distinction, ${ }^{74}$ this suggests a two-fold extension: First, to look behind the well-structured segments of a chain that 'contract governance' typically sheds light on, and second, to include the more invasive disciplinary techniques that are used in supply chain governance while being under the radar of contract scholars for the most part. These include regulatory techniques classically attributed to state legislation which have growingly entered the private sphere, such as surveillance tools. Along which lines, through which tools and vehicles does power ${ }^{75}$ in supply chains travel and what are its informal instantiations? Contract law can thereby contribute to bridging a growing disconnect between the impact of GVCs on the "human condition"76 and individual realities on the one hand and their reliance on distant, expert-driven, impersonal techniques here assimilated under the term of 'governmentality'. Modes of governmentality become pervasive beyond the contractual sphere and in ways that are only beginning to be illuminated by contract scholarship, especially with regard to data-driven and algorithmic governance. ${ }^{77}$ In such a perspective, governance

73 See eg V. Vytopil, Contractual Control in the Supply Chain. On Corporate Social Responsibility, Codes of Conduct, Contracts and (Avoiding) Liability (The Hague: Eleven International Publishing, 2015); K. Mitkidis, S. Perkovic and P. Mitkidis, 'Tendencies in contractual governance to promote human and labour rights in transnational supply chains' 23 Competition \& Change 397-419 (2019); and V. Ulfbeck, O. Hansen and A. Andhov, 'Contractual enforcement of CSR clauses and the protection of weak parties in the supply chain', in V. Ulfbeck, A. Andhov and K. Mitkidis (eds), Law and Responsible Supply Chain Management: Contract and Tort Interplay and Overlap (Oxford: Routledge, 2019); explicitly in a perspective of 'reimagining' existing contract law V. Ulfbeck and O. Hansen (in this issue).

74 M. Foucault, 'Governmentality', in G. Burchell, C. Gordon and P. Miller (eds), The Foucault Effect (Chicago: University of Chicago Press, 1991) 87-104.

75 On 'power' as a per se de-personalizing category cf G. Deleuze, 'Schluss mit dem Gericht', in Kritik und Klinik (Frankfurt aM: Suhrkamp, 2000) 171.

76 A. Tsing, 'Supply Chains and the Human Condition' 21 Rethinking Marxism: A Journal of Economics, Culture \& Society 148-176 (2009); for further discussion cf Zumbansen, $\mathrm{n} 38$ above.

77 See powerfully J. Cohen, Between Truth and Power: The Legal Constructions of Informational Capitalism (Oxford: Oxford University Press, 2019). 
never operates in an aseptic space, but addresses and processes pre-existing management cultures, ideologies undergirding regulatory modes as well as individual and collective dispositions. ${ }^{78}$ To depict the actual animating logic(s) behind current GVCs, it seems necessary to acknowledge these entangled dynamics, at times in the blind spots of liberal theories which adopt a more emphatic normative orientation. ${ }^{79}$ This broadens the array of instruments to be considered in contract governance analysis-just like public international law has recently begun to theorize informal and knowledge-driven governance through a related lens. ${ }^{80}$ Some disciplinary practices will go wholly unnoticed by contractual analysis, such as the use of an informal workforce, or the forestalling of contractual penalties through deposits. At the same time, contracts can become communicative devices that embody normative convictions and assume a critical role in 'voicing the market'. ${ }^{81}$

The idea of an 'embeddedness' of production in a wider spatial, social, economic and normative context that is connected through various regulatory modes is not unfamiliar to theorists of global production. More specifically, the 'Global Production Network' 82 frame echoes the fact that despite lead firm coordination, there is a critical number of indirect and contextual influences that are discarded in the overly linear 'chain' metaphor. As an example, this literature highlights the diverse set of practices such as those enculturated in supply chain management which animate production. ${ }^{83}$

78 See eg L. Catá Backer, 'Theorizing regulatory governance within its ecology: The structure of management in an age of globalization' 24 Contemporary Politics 607-630 (2018).

79 See for an engagement with corporate wrongs along GVCs based on 'private law's normative DNA' H. Dagan and A. Dorfman, 'Interpersonal Human Rights' 51 Cornell International Law Journal 351-390 (2018).

80 Notably M. Goldmann, Internationale öffentliche Gewalt. Handlungsformen internationaler Institutionen im Zeitalter der Globalisierung (Heidelberg: Springer, 2015).

81 R. Kreitner, 'Voicing the market: Extending the ambition of contract theory' 69 University of Toronto Law Journal 295-336 (2019).

82 See eg N. Coe, P. Dicken and M. Hess, 'Global Production Networks: Realizing the Potential' 8 Journal of Economic Geography 271-295 (2008); N. Coe and H.W.-C. Yeung, Global Production Networks: Theorizing Economic Development in an Interconnected World (Oxford: Oxford University Press, 2015); N.M. Coe and H.W.-C. Yeung, 'Global Production Networks: Mapping Recent Conceptual Developments' 19 Journal of Economic Geography 775-801 (2019); for a comparison with the GVC framework cf J. Bair, 'Analysing economic organization: embedded networks and global chains compared' 37 Economy and Society 339-364 (2008).

83 P. Gibbon and S. Ponte, ‘Global Value Chains: From Governance to Governmentality?’ 37 Economy and Society 365-392 (2008); F. Palpacuer, 'Bringing the Social Context Back in: Governance and Wealth Distribution in Global Commodity Chains’ 37 Economy and Society 393-419 (2008). 


\section{Regulating the 'Code' of Global Value Chains: Rethinking the Role of Law in Infrastructure}

Shifting from an actor-centric analysis to an analysis of tools of governmentality entails a focus on the material, technological and digital infrastructure ${ }^{84}$ of GVCs. This infrastructure is crucial for the seamlessness of operations along the chain and shapes the flow of production, as illustrated by most lead firms' attempts to design infrastructural support specific to their respective GVC. More generally, 'infrastructure' serves as a material channel through which 'goods, ideas, waste, power, people and finance are trafficked' ${ }^{85}$ Vis-à-vis law, such infrastructure seems to stand in a recursive relation. On the one hand, it can be the target of regulation and then has to abide with normative constraints. On the other hand, infrastructure may set into motion technical, logistical or managerial processes that can themselves embody normative orientations, such as favouring the speed of delivery to a thorough assessment of rights violations. Once implemented, infrastructure brings about high path-dependency and is resistant to targeted change. Scholarship on "legal materiality" ${ }^{86}$ and generally socio-legal studies ${ }^{87}$ can be used to illustrate how infrastructure is normatively conducive and immersed and reshaping the effectiveness of governance. The design of a port or transport hub, a user's interface of a supply-chain management software or a spreadsheet template for a quality audit may well prove to be more impactful than a contractual clause or piece of legislation. The rise of quantitative assessment, benchmarking and indicators of product quality, most recently also in the field of

84 Cf on the concept B. Larkin, 'The Politics and Poetics of Infrastructure' 42 Annual Review of Anthropology 327-343 (2013); S. Star, 'The Ethnography of Infrastructure' 43 American Behavioral Scientist 377-391 (1999); J. Urry, 'The "System” of Automobility' 21 Theory, Culture and Society 2539 (2004), N. Rossiter, Software, Infrastructure, Labor: A Media Theory of Logistical Nightmares (London: Routledge, 2016); specifically with regard to GVCs N.M. Coe, 'Missing Links: Logistics, Governance and Upgrading in a Shifting Global Economy' 21 Review of International Political Economy 224-256 (2014); for a legal unpacking B. Kingsbury, 'Infrastructure and InfraReg: On Rousing the International Law “Wizards of Is”” 8 Cambridge International law Journal 171-186 (2019).

85 Cf Larkin, $\mathrm{n} 84$ above, 327.

86 For an overview H.Y. Kang and S. Kendall, 'Legal Materiality', in M. Del Mar, B. Meyler and S. Stern (eds), Oxford Handbook for Law and the Humanities (Oxford: Oxford University Press, 2020, forthcoming); A. Pottage, 'The Materiality of What?' 39 Journal of Law and Society 167-183 (2012). Main references stem from Actor-Network-Studies (ACT) or Science and Technology Studies (STS); for a trailblazing account of business practices see A. Riles, Collateral Knowledge: Legal Reasoning in the Global Financial Markets (Chicago: University of Chicago Press, 2011).

87 Such as for a socio-legal understanding of categories of 'control' and 'governance'; see generally on this idea R. Cotterell, 'Why Must Legal Ideas Be Interpreted Sociologically?' 25 Journal of Law and Society 171-192 (1998). 
sustainability, will further deepen this trend. ${ }^{88}$ Such normative underpinnings have occasionally been recognized for the field of logistics so far. ${ }^{89}$

To express the intrinsic relation between infrastructure and the legal side of GVCs, both together can be said to form the 'code' of GVCs. As in its famous use by Lessig $^{90}$ for cyberspace and lately by Pistor $^{91}$ for the legal construction of capital, 'code' is used here to depict the closed-circuited, systemic nature of GVCs which jointly results from a legal as well as a material, technological or epistemic dimension. The 'code' of GVCs, in this understanding, is what only enables them to spin into overdrive and has to be the focus of any attempt to regulate GVCs from the outset. Accordingly, GVCs are no mere object of regulation, but themselves constitutive of a normative order that makes them work and lends them their current shape.

\section{Conclusion}

As private law begins to address the institutional shape of contemporary production, ${ }^{92}$ we have seen that it will be insufficient to move along the lines of a continuum between 'firm' and 'market'. This classical demarcation from institutional economics is prominent in the micro-level-oriented framework of GVC analysis and finds easy correspondence in legal thought. It is hence not surprising that it undergirds the majority of scholarly but also legal reform projects in the field. Yet, because of global value chains' double nature as a micro-level organizational arrangement and a macro-level stage in the evolution of a global political economy, its challenges would be too narrowly addressed by the creation of a novel 'legal

88 See only G. Sarfaty, 'Regulating Through Numbers: A Case Study of Corporate Sustainability Reporting' 53 Virginia Journal of International Law 575-621 (2013).

89 For a study on supermarket infrastructure cf A. Cohen, 'Supermarkets in India: Struggles over the Organization of Agricultural Markets and Food Supply Chains' 68 University of Miami Law Review 19-86 (2013); A. Cohen, 'Transnational legal methodology and domestic markets for food' 9 Transnational Legal Theory 361-370 (2018); on logistics generally G. Sarfaty, 'Supply Chains and Logistics', in M. Valverde et al (eds), Routledge Handbook of Law and Society (London: Routledge, 2020, forthcoming); for a comprehensive research agenda the 'Infrastructures as Regulation' (InfraReg) project at NYU School of Law, cf https://www.iilj.org/infrareg/infrareg-project/.

90 L. Lessig, Code and other laws of cyberspace (New York: Basic Books, 1999).

91 Pistor, $\mathrm{n} 30$ above.

92 On the question of transposing the GVC framework with its roots in industrial policy to valuecreating processes of the digital economy cf I. Lianos and K.H. Eller, 'The Private Governance of Digital Value Chains', in BRICS Competition Law Project (ed), Digital Era Competition BRICS Report (2019) ch 3. 
concept' or a specific legal reform-although recurring rules of conduct and liability that are tailored to chain contexts can be identified. Rather, this article has advocated an understanding of GVCs as a 'legal heuristic' that requires private law-and contract law in particular-to revisit its epistemological basis in order to overcome a conceptual disjunction that presently characterizes global production. A central obstacle has been the neglect of social institutions that emerge from the aggregate use of private autonomy.

To grasp the reality of fissured and fragmented agency requires interdisciplinary input that reaches beyond what a single social science can teach legal analysis. Adopting a perspective of 'methodological pluralism', ${ }^{93}$ this article has argued that GVCs are themselves constitutive of a normative order that employs a broad array of techniques beyond the scope of 'contract governance'. Such disciplinary practices-here termed as 'contract governmentality'-arise across all tiers up until the very bottom, and build on informal, social, data-driven, arithmetic or technological powers. Oftentimes, these are not generated from scratch, but are in-built into the physical, informational or technological infrastructure of a chain. To express the close ties between this infrastructure and the contractual governance, both elements are here referred to under the joint terminology of the 'code' of global value chains. Gearing contract analysis towards the 'code' of GVCs will allow a realist account of the complexity of chain relationships beyond the first tiers and thereby enable an easier connection with the broad interdisciplinary field of studies around global production.

93 S. Grundmann, 'Pluralism and Private Law Theory', manuscript 2019; for an early plea against a monistic legal reception of social sciences R. Wiethölter, 'Social Science Models in Economic Law', in T. Daintith and G. Teubner (eds), Contract and Organisation. Legal Analysis in the Light of Economic and Social Theory (Berlin / New York: de Gruyter, 1986) 52-67. 